\title{
POSTOPERATIVE THINNING OF LAMELLAR DONOR GRAFT AFTER CONVENTIONAL DESCEMET'S STRIPPING AUTOMATED ENDOTHELIAL KERATOPLASTY
}

\author{
Ana Meter ${ }^{1}$, Tomislav Kuzman ${ }^{1}$, Miro Kalauz ${ }^{1}$, Ivan Škegro ${ }^{1}$, Sanja Masnec ${ }^{1}$ and Josip Pavan² \\ ${ }^{1}$ Department of Ophthalmology, Zagreb University Hospital Centre, School of Medicine, University of Zagreb, \\ Zagreb, Croatia; ${ }^{2}$ Department of Ophthalmology, Dubrava University Hospital, Zagreb, Croatia
}

\begin{abstract}
SUMMARY - The purpose of this study was to evaluate postoperative deturgescence of lamellar donor graft after conventional Descemet's stripping automated endothelial keratoplasty (DSAEK). It was a prospective study that included 55 eyes of patients (mean age $70.9 \pm 9.4$ years; female $61.8 \%$, male $38.2 \%)$. Preoperative thickness of lamella was compared with postoperative thickness six months after surgery. Central lamellar graft thickness decreased from $142 \pm 27 \mu \mathrm{m}$ preoperatively to $124 \pm 20 \mu \mathrm{m} 6$ months postoperatively $(\mathrm{p}<0.01)$. After performing conventional DSAEK corneal transplantation, surgeons should expect deturgescence of corneal graft and reduction in thickness of lamellae by about $12 \%$ of initial thickness according to our results. We found this information important for better planning of surgical procedures and knowing what to expect after surgery, as well as for better cooperation with eye banks when ordering pre-cut corneal tissue.
\end{abstract}

Key words: Descemet stripping endothelial keratoplasty; Cornea; Corneal pachymetry; Tomography, optical coherence

\section{Introduction}

Penetrating keratoplasty (PKP) was the gold standard of corneal transplantation in the past. Corneal transplantation is a procedure by which the patient's blurred cornea is replaced by a clear donor cornea. During the past decade, new corneal transplantation techniques were developed. It is possible to transplant the inner or outer corneal layer. For the diseases of corneal endothelium, which is the most inner layer of the cornea, PKP was replaced with lamellar endothelial keratoplasty procedures. Currently, the most common endothelial keratoplasty procedures are Descemet

Correspondence to: Asst. Prof. Tomislav Kuzman, MD, PhD, Department of Ophthalmology, Zagreb University Hospital Centre, School of Medicine, University of Zagreb, Kišpatićeva 12, HR10000 Zagreb, Croatia

E-mail: tkuzman@kbc-zagreb.hr

Received September 24, 2018, accepted October 18, 2018 membrane endothelial keratoplasty (DMEK) and Descemet stripping automated endothelial keratoplasty (DSAEK) $)^{1}$. DSAEK was introduced in 2006 by Price and Price ${ }^{2}$ and Gorovoy ${ }^{3}$, and has become the most frequently performed technique for corneal endothelium replacement. Compared with PKP, patients undergoing DSAEK experience faster recovery of vision without problems of high astigmatism and open-sky surgery ${ }^{4}$.

Preparation of DSAEK lamellar donor graft is usually performed in eye banks with slightly different procedures. Graft is pre-cut in the eye bank with automated microkeratomes because manual preparation of endothelial grafts proved to be a difficult and time consuming procedure ${ }^{5}$. To date, controversial results have been reported regarding correlation between thickness of lamellar grafts and final visual outcome. Some studies suggest that thinner postoperative grafts may lead to better final visual acuity ${ }^{6-9}$. However, other studies 
found no correlation with postoperative graft thickeness and vision ${ }^{10-13}$. In an attempt to achieve better vision outcomes while obtaining the same low rates of postoperative complications of conventional DSAEK surgery, some surgeons have begun using thinner DSAEK grafts, requesting that eye banks produce this thin tissue for their use, increasing the risk of tissue loss for eye banks.

Futher development in DSAEK graft preparation is pushing towards more delicate and thinner lamellae, so we can describe nanothin (NT, $\leq 50 \mu \mathrm{m})$, ultrathin (UT, $\leq 100 \mu \mathrm{m})$ and conventional $(\geq 100 \mu \mathrm{m})$ grafts $^{14}$.

During development of the DSAEK method, there was a change in the definition of the method subtypes depending on the thickness of the lamella. Previously defined as ultrathin DSAEK were lamellae thinner than $130 \mu \mathrm{m}$, although today it is considered as being thinner than $100 \mu \mathrm{m}^{6,8,14}$. These definitions are accepted by agreement of the surgeons and are not strictly defined, as confirmed by the study conducted by Chamberlain et al., where $56 \%$ of experienced surgeons took lamellar thickness $<100 \mu \mathrm{m}$ as ultrathin and $>100 \mu \mathrm{m}$ as conventional DSAEK method ${ }^{15}$.

The question that is imposed is when the lamella is measured. The first measurement is performed in the eye bank during preparation of the lamella and these data are available to the surgeons before surgery. Thickness of the lamellae measured in the eye bank can be taken to define it as ultrathin or conventional DSAEK. In tissue bank, the lamellae are usually measured by ultrasound pachymetry, which is the gold standard for corneal thickness measurement. However, many surgeons measure thickness of the lamella after transplantation. Ocular coherent tomography (OCT) device can measure thickness of the cornea and lamella with exceptional precision, and is usually used to measure cornea postoperatively. According to some authors, the final thickness of the lamella stabilizes four months after the surgery, and most of the measurements performed at six months after the surgery are considered definite ${ }^{7,13}$.

Several authors found that thickness of the lamellae measured in the eye bank preoperatively and postoperatively did not correspond. It was recognized that after cutting, the graft underwent deturgescence and became thinner ${ }^{11,16-18}$.

The purpose of this study was to assess the correlation between preoperative thickeness of the lamellae measured in the eye bank and final postoperative thickness of the lamellae. Inclusion criteria were lamellae that met the definition of conventional DSAEK. Our interest was focused on conventional DSAEK because it is the most widely used method of endothelial keratoplasty that has also been performed in our eye bank.

\section{Patients and Methods}

This prospective study enrolled 55 eyes of patients having undergone DSAEK corneal transplantation. Inclusion criteria were corneal edema secondary to Fuchs endothelial dystrophy and pseudophakic bullous keratopathy. Exclusion criteria were lamellar donor grafts thinner than $100 \mu \mathrm{m}$ because this tissue processing for ultrathin or nanothin DSAEK is different than for conventional standard DSAEK and it is not performed in our eye bank. Lamellar thickness was measured by anterior OCT on a Visante OCT device (Carl Zeiss Meditec, Jena, Germany), which is a noninvasive, non-contact imaging method that provides a high micrometric resolution of eye tissue sections. It is analogous to ultrasound, but it uses near-infrared interferometry instead of sound waves, and the image is created based on the analysis of interference between the reflected reference waves and those reflecting from the tissue.

The corneas are stored at the Zagreb University Hospital Centre Eye Bank in a medium for hypothermic storage and tissue culture media. The corneas can be prepared for lamellar keratoplasty after storage in both types of media. Corneas can be stored in a hypothermic storage medium at a temperature of $4{ }^{\circ} \mathrm{C}$ for a maximum of 7 days, and are prepared for lamellar keratoplasty before the planned operation. Most of the corneas are kept in tissue culture medium at a temperature of $31{ }^{\circ} \mathrm{C}$ for a maximum of 28 days. During storage in tissue culture, the medium is microbiologically controlled and at end of storage the endothelial cell viability and morphology is estimated. The cornea becomes much thicker during storage in tissue culture. To return to the physiological thickness, it must be stored in transport medium containing dextran for at least 24 hours before preparation for lamellar keratoplasty. Due to the short corneal validity in the transport medium (depending on the manufacturer, Alchemy 5 days, Eurobio 4 days), the cornea is placed in 
transport medium only when it is assigned to the particular patient. Transport medium is kept until the third microbiological control, which is taken in the incubator at $31{ }^{\circ} \mathrm{C}$. After taking the microbiological control, it is kept in the thermostat at $22{ }^{\circ} \mathrm{C}$ until release.

The procedure of preparing the cornea for lamellar keratoplasty is performed by specially trained staff members using the automatic microkeratome (Gebauer Slc Original, Neuhausen, Germany). The cornea is placed in the artificial eye chamber filled with corneal storage medium to preserve the endothelial cell viability. The epithelium of the cornea is removed to make the cut as regular as possible. Central corneal thickness is measured by ultrasound pachymetry (Pachette 4 DGH555B, DGH Technology, Exton, USA). At least 5 measurements are performed centrally and the mean value is calculated. Applanation of donor cornea is performed and diameter of the lamella (depending on the cornea, $9-10 \mathrm{~mm}$ ) is determined. Due to the tendency of corneal dehydration, thickness of the cornea is measured again and appropriate knife size for cutting is chosen according to the lamella target thickness. The permissible variation of the knife, which is 30 $\mu \mathrm{m}$, should be considered. Immediately after cutting, thickness of the lamella is measured with ultrasound pachymetry. The cornea is carefully removed from the artificial eye chamber and stored in transport medium for delivery to transplantation center.

All surgeries were performed by two surgeons under general anesthesia. After successful conventional DSAEK transplantation, patients were examined postoperatively at Department of Ophthalmology, Zagreb University Hospital Centre; final measurement of corneal and lamellar thickness was performed by anterior OCT six months after surgery. Preoperative and postoperative lamellar thickness was compared.

The study was approved by the local Ethics Committee and all patients signed the informed consent form to take part in the study.

\section{Statistics}

Microsoft SPSS statistical package for Windows was used. Results were expressed as mean and standard deviation (SD). Differences between the groups were tested by Student's T-test. The level of statistical significance was set at $\mathrm{p}<0.05$.

\section{Results}

The study included 55 eyes of patients having undergone DSAEK, mean age $70.9 \pm 9.4$ (range 48 to 87 ) years. There were $61.8 \%(n=34)$ of female patients and $38.2 \%(n=21)$ of male patients. Central graft thickness before surgery measured by ultrasound pachymetry ranged from 110 to $198 \mu$ m, mean $142 \pm 27 \mu \mathrm{m}$. Central graft thickness six months after surgery measured by anterior OCT ranged from 100 to $187 \mu \mathrm{m}$, mean $124 \pm 20 \mu \mathrm{m}$. Statistical analysis of the mean lamellar values measured before and after surgery yielded a statistically significant difference in the thickness of the lamellae before and after the surgery $(t=5.148, p<0.01)$, i.e. the subjects had a statistically significantly greater thickness of the lamellae before the surgery $(M=142.16)$ compared to thickness after the surgery $(M=123.93)$ (Table 1).

Table 1. T-test for central lamellar thickness before and after the surgery

\begin{tabular}{|l|l|l|l|}
\hline & & Mean (SD) & $\mathrm{t}$ \\
\hline $\begin{array}{l}\text { Lamellar } \\
\text { thickness } \\
(\mu \mathrm{m})\end{array}$ & Preoperative & $142.16(27.193)$ & \multirow{2}{*}{$5.148^{*}$} \\
\cline { 2 - 4 } & Postoperative & $123.93(20.288)$ & \\
\hline
\end{tabular}

*p $<0.01$

We evaluated corneal deturgescence after conventional DSAEK by comparing preoperative and postoperative central lamellar thickeness. Lamellar thickness measurement taken six months after conventional DSAEK surgery revealed the mean $12 \%$ deturgescence of lamellae.

\section{Discussion}

Many corneal surgeons require accurate measurement of corneal grafts from the eye banks. There have been many studies related to visual outcomes regarding lamellar thickness and definite visual outcome, but the results are still controversial ${ }^{6-13}$. One of the possible reasons for the controversy may be errors in measuring lamellar thickness before surgery. Therefore, accurate measurement could provide valuable information for surgeons.

Corneal deturgescence begins immediately after cutting, as demonstrated by Tang et al. They showed 
Table 2. Deturgescence of lamellae recorded by different study groups

\begin{tabular}{|l|l|l|l|l|}
\hline Authors & $\begin{array}{l}\text { Preoperative lamellar } \\
\text { thickness }(\mu \mathrm{m}) / \text { method } \\
\text { of measurement }\end{array}$ & $\begin{array}{l}\text { Postoperative lamellar } \\
\text { thickness }(\mu \mathrm{m}) / \text { method } \\
\text { of measurement }\end{array}$ & $\begin{array}{l}\text { Diference in } \\
\text { lamellar thickness } \\
(\mu \mathrm{m})\end{array}$ & $\begin{array}{l}\text { Mean } \\
\text { deturgescence } \\
\text { after surgery }(\%)\end{array}$ \\
\hline Di Pascuale et al. ${ }^{11}$ & 243/OCT & $148 / \mathrm{OCT}$ & 95 & 39 \\
Woodward et al. ${ }^{19}$ & 199/Pachymetry & $165 / \mathrm{OCT}$ & 34 & 17 \\
Tang et al. ${ }^{16}$ & $189 / \mathrm{OCT}$ & 41 & 22 \\
Romano et al..$^{17}$ & 83/OCT & $78^{* *} / \mathrm{OCT}$ & 13 & 15 \\
Meter et al. & 142/Pachymetry & $124 / \mathrm{OCT}$ & 18 & 12 \\
\hline
\end{tabular}

*four hours after cutting; **3 months postoperatively; OCT = ocular coherent tomography

that DSAEK grafts became thinner after microkeratome cut from $189 \mu \mathrm{m}$ immediately after cutting to $148 \mu \mathrm{m}$ after four hours. Therefore, they suggest that DSAEK graft thickness should be measured at 1.5-3 hours after microkeratome $\operatorname{cut}^{16}$ (Table 2).

The probable cause of lamellar swelling after cutting is irrigation of balanced salt solution (BSS) for cleaning the graft, and may even be greater with removal of epithelium, which is also usually performed before cutting. There are numerous techniques of tissue cutting, epithelium removal and transport media used, which can affect tissue thickness. Our study compared lamellae of $>100 \mu \mathrm{m}$ defined as a standard conventional DSAEK procedure, which is performed in our institution and in our eye bank. Tissue processing for ultrathin DSAEK is different than for conventional DSAEK, which includes a double cut microkeratome technique, a femtosecond laser technique and a high-pressure single cut microkeratome technique $^{17}$.

It is recognized that after cutting and transplanting the graft into the eye, the graft undergoes deturgescence and becomes thinner. Di Pascuale et al. report that the mean graft thickness decreased from $243 \mu \mathrm{m}$ on day 1 postoperatively to $148 \mu \mathrm{m}$ at the last visit, stabilizing approximately six months after the surgery. In their study, $39 \%$ thinning was recorded ${ }^{11}$. Even with thinner grafts, as in the study by Romano et al., with the mean post-cut thickness of $83 \mu \mathrm{m}$, the mean thickness decreased to $70 \mu \mathrm{m}$ at 3 months postoperatively, with the mean $15 \%$ thinning ${ }^{18}$. Woodward et al. report on deturgescence from $199 \mu \mathrm{m}$ preoperatively to 165 $\mu \mathrm{m}$ postoperatively, with the mean thinning of $17 \%{ }^{19}$. The above mentioned studies show that thicker grafts undergo greater deturgescence than thinner grafts. Results of our study showed deturgescence from 142 $\mu \mathrm{m}$ to $124 \mu \mathrm{m}$, with the mean $12 \%$ thinning ( $<<0.01$ ). It was somewhat lower than in other studies, which can be explained by different methods of measurement with preoperative ultrasound pachymetry and more precise anterior OCT postoperatively. A similar study was conducted by Woodward et al. ${ }^{19}$ on 64 eyes with the same measurement methods, and our results are consistent with their findings.

In conclusion, after performing conventional DSAEK corneal transplantation, surgeons should expect deturgescence of corneal graft and reduction in thickness of lamellae by about $12 \%$ of initial thickness according to our study. We found this information important for better planning of surgical procedures and knowing what to expect after surgery, as well as for better cooperation with eye banks when ordering precut corneal tissue.

\section{References}

1. Melles GR. Posterior lamellar keratoplasty: DLEK to DSEK to DMEK. Cornea. 2006;25:879-81. doi: 10.1097/01.ico.0000243962.60392.4f

2. Price MO, Price FW Jr. Descemet's stripping with endothelial keratoplasty: comparative outcomes with microkeratome-dissected and manually dissected donor tissue. Ophthalmology. 2006;113:1936-42. doi: 10.1016/j.ophtha.2006.05.034

3. Gorovoy MS. Descemet-stripping automated endothelial keratoplasty. Cornea. 2006;25:886-9. doi: 10.1097/01.ico.0000214224.90743.01

4. Bahar I, Kaiserman I, McAllum P, et al. Comparison of posterior lamellar keratoplasty techniques to penetrating keratoplasty. Ophthalmology. 2008;115:1525-33. doi: 10.1016/j.ophtha.2008.02.010

5. Lee WB, Jacobs DS, Musch DC, Kaufman SC, Reinhart WJ, Shtein RM. Descemet's stripping endothelial keratoplasty: safety and outcomes: a report by the American Academy 
of Ophthalmology. Ophthalmology. 2009;116:1818-30. doi: 10.1016/j.ophtha.2009.06.021

6. Maier AK, Gundlach E, Klamann MK, Gonnermann J, Bertelmann E, Joussen AM, Torun N, Rieck PW. Influence of donor lamella thickness on visual acuity after Descemet's stripping automated endothelial keratoplasty. Ophthalmologe. 2014; 111:128-34. doi: 10.1007/s00347-013-2795-0

7. Pogorelov P, Cursiefen C, Bachmann BO, Kruse FE. Changes in donor corneal lenticule thickness after Descemet's stripping automated endothelial keratoplasty (DSAEK) with organcultured corneas. Br J Ophthalmol. 2009;93:825-9. doi: 10.1136/bjo.2008.147389

8. Neff KD, Biber JM, Holland EJ. Comparison of central corneal graft thickness to visual acuity outcomes in endothelial keratoplasty. Cornea. 2011;30:388-91. doi: 10.1097/ICO.0b013e3181f236c6

9. Dickman MM, Cheng YY, Berendschot TT, van den Biggelaar FJ, Nuijts RM. Effects of graft thickness and asymmetry on visual gain and aberrations after Descemet stripping automated endothelial keratoplasty. JAMA Ophthalmol. 2013;131: 737-44. doi: 10.1001/jamaophthalmol.2013.73

10. Nieuwendaal CP, van Velthoven ME, Biallosterski C, et al. Thickness measurements of donor posterior disks after Descemet stripping endothelial keratoplasty with anterior segment optical coherence tomography. Cornea. 2009;28:298-303. doi: 10.1097/ICO.0b013e318189135f

11. Di Pascuale MA, Prasher P, Schlecte C, et al. Corneal deturgescence after Descemet stripping automated endothelial keratoplasty evaluated by Visante anterior segment optical coherence tomography. Am J Ophthalmol. 2009;148:32-7. doi: 10.1016/j. ajo.2009.01.016

12. Ahmed KA, McLaren JW, Baratz KH, et al. Host and graft thickness after Descemet stripping endothelial keratoplasty for
Fuchs endothelial dystrophy. Am J Ophthalmol. 2010;150: 490-7. doi: 10.1016/j.ajo.2010.05.011

13. Shinton AJ, Tsatsos M, Konstantopoulos A, et al. Impact of graft thickness on visual acuity after Descemet's stripping endothelial keratoplasty. Br J Ophthalmol. 2012;96:246-9. doi: 10.1136/bjophthalmol-2011-300462

14. Cheung AY, Hou JH, Bedard P, Grimes V, Buckman N, Eslani $\mathrm{M}$, Holland EJ. Technique for preparing ultrathin and nanothin Descemet stripping automated endothelial keratoplasty tissue. Cornea.2018;37:661-6. doi: 10.1097/ICO.0000000000001510

15. Chamberlain W, Austin A, Terry M, Jeng BH, Rose-Nussbaumer J. Survey of experts on current endothelial keratoplasty techniques. J Clin Exp Ophthalmol. 2016;7:608.

doi: $10.4172 / 2155-9570.1000608$

16. Tang M, Stoeger C, Galloway J, Holiman J, Bald MR, Huang D. Evaluating DSAEK graft deturgescence in preservation medium after microkeratome cut with optical coherence tomography. Cornea. 2013;32:847-50. doi: 10.1097/ICO.0b013e31828a27dd

17. Peron T, Shtein R, Titus M, Woodward M. Tissue processing for ultra-thin Descemet stripping automated endothelial keratoplasty. Int J Eye Banking. 2014:2:1-5. doi: 10.7706/ijeb.v2i1.61

18. Romano V, Steger B, Myneni J, Batterbury M, Willoughby $\mathrm{CE}$, Kaye SB. Preparation of ultrathin grafts for Descemetstripping endothelial keratoplasty with a single microkeratome pass. J Cataract Refract Surg. 2017;43:12-5. doi: 10.1016/j. jcrs.2016.12.009

19. Woodward MA, Raoof-Daneshvar D, Mian S, Shtein RM. Relationship of visual acuity and lamellar thickness in Descemet stripping automated endothelial keratoplasty. Cornea. 2013;32:69-73. doi: 10.1097/ICO.0b013e318271fc99

Sažetak

POSLIJEOPERACIJSKO SMANJIVANJE DEBLJINE DONORSKE ROŽNIČNE LAMELE NAKON KONVENCIONALNE STRAŽNJE SLOJEVITE TRANSPLANTACIJE ROŽNICE

\section{A. Meter, T. Kuzman, M. Kalauz, I. Škegro, S. Masnec i J. Pavan}

Svrha ovoga istraživanja bila je procjena poslijeoperacijske deturgescencije donorske rožnične lamele nakon konvencionalne stražnje slojevite transplantacije rožnice (engl. Descemet's stripping automated endothelial keratoplasty). U ovu prospektiv-

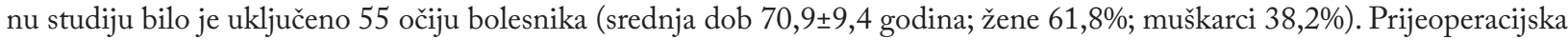
debljina lamele uspoređena je s poslijeoperacijskom debljinom šest mjeseci nakon transplantacije. Centralna debljina donorske lamele smanjila se s prijeoperacijskih $142 \pm 27 \mu \mathrm{m}$ na $124 \pm 20 \mu \mathrm{m}$ šest mjeseci nakon operacije ( $<<0,01)$. Prema rezultatima očekivano stanjivanje donorske rožnične lamele nakon konvencionalne stražnje slojevite transplantacije iznosilo je u prosjeku $12 \%$ od početne debljine. Smatramo da je taj podatak važan zbog boljeg planiranja operacijskog zahvata stražnje slojevite transplantacije rožnice i preciznijeg naručivanja rožničnog tkiva iz očne banke.

Ključne riječi: Keratoplastika; Rožnica; Rožnica, pabimetrija; Tomografja, optička koherentna 